\title{
Cellular immune response to SARS-CoV-2 infection in humans: a systematic review
}

\author{
AUTHORS \\ Madhumita Shrotri ${ }^{1,3 \dagger *}$, May C. I. van Schalkwyk ${ }^{2 \dagger}$, Nathan Post ${ }^{1}$, Danielle Eddy ${ }^{3}$, Catherine \\ Huntley ${ }^{1}$, David Leeman ${ }^{3}$, Samuel Rigby ${ }^{1}$, Sarah V. Williams ${ }^{1}$, William H. Bermingham ${ }^{4}$, Paul \\ Kellam $^{5}$, John Maher ${ }^{6,7}$, Adrian M. Shields ${ }^{8}$, Gayatri Amirthalingam ${ }^{3}$, Sharon J. Peacock ${ }^{3,9}$, \\ Sharif A. Ismail ${ }^{3,10}$
}

${ }^{1}$ Faculty of Public Health and Policy, London School of Hygiene and Tropical Medicine, UK

${ }^{2}$ Department of Public Health, Environments and Society, London School of Hygiene and Tropical Medicine, UK

${ }^{3}$ National Infection Service, Public Health England, UK

${ }^{4}$ Department of Clinical Immunology, University Hospitals Birmingham, UK

${ }^{5}$ Department of Infectious Disease, Faculty of Medicine, Imperial College London, UK

${ }^{6}$ School of Cancer and Pharmaceutical Studies, King's College London, UK

${ }^{7}$ Department of Immunology, Eastbourne Hospital, UK

${ }^{8}$ Clinical Immunology Service, Institute of Immunology and Immunotherapy, University of Birmingham, UK

${ }^{9}$ Department of Medicine, University of Cambridge, UK

${ }^{10}$ Department of Global Health and Development, London School of Hygiene and Tropical Medicine, UK

${ }^{\dagger}$ Denotes joint first author.

* Denotes corresponding author.

\section{CORRESPONDING AUTHOR}

Dr Madhumita Shrotri

Faculty of Public Health and Policy

London School of Hygiene and Tropical Medicine

Keppel Street

London WC1E 7HT

United Kingdom

madhumita.shrotri1@nhs.net 


\section{KEYWORDS}

Human, immunity, T cell, CD4, CD8, SARS-CoV-2, COVID-19

\section{LIST OF ABBREVIATIONS}

\begin{tabular}{|l|l|}
\hline Abbreviation & Full term \\
\hline ARDS & Acute respiratory distress syndrome \\
\hline COVID-19 & Coronavirus disease (2019) \\
\hline CRS & Cytokine release syndrome \\
\hline ELISpot & Enzyme-linked immune absorbent spot (assay) \\
\hline HCoV & Human Coronavirus (HKU1, 229E, OC43, NL63) \\
\hline IFN-Y & Interferon gamma \\
\hline M & Membrane (protein) \\
\hline MEDLINE & Medical Literature Analysis and Retrieval System Online \\
\hline MERS & Middle East Respiratory Syndrome \\
\hline MetaQAT & Meta Quality Appraisal Tool \\
\hline NP & Nucleocapsid protein \\
\hline NSP7; NSP13 & Non-structural protein 7; non-structural protein 13 \\
\hline PBMC & Peripheral blood mononuclear cells \\
\hline PCR; RT-PCR & Polymerase chain reaction; reverse transcription polymerase chain reaction \\
\hline PRISMA & Preferred Reporting Items for Systematic Reviews and Meta-Analyses \\
\hline SARS-CoV-1 & Severe Acute Respiratory Syndrome Coronavirus-1 \\
\hline SARS-CoV-2 & Severe Acute Respiratory Syndrome Coronavirus-2 \\
\hline RBD & Receptor binding domain \\
\hline RNA & Ribonucleic acid \\
\hline TEMRA & T effector memory cells re-expressing CD45RA \\
\hline TFH; cTFH & T follicular helper cells; circulating T follicular helper cells \\
\hline Th & T helper cells \\
\hline WHO & World Health Organization \\
\hline
\end{tabular}




\section{ABSTRACT}

\section{Introduction}

Understanding the cellular immune response to SARS-CoV-2 is critical to vaccine development, epidemiological surveillance and control strategies. This systematic review critically evaluates and synthesises the relevant peer-reviewed and pre-print literature published in recent months.

\section{Methods}

For this systematic review, independent keyword-structured literature searches were carried out in MEDLINE, Embase and COVID-19 Primer for studies published from 01/01/2020-26/06/2020. Papers were independently screened by two researchers, with arbitration of disagreements by a third researcher. Data were independently extracted into a pre-designed Excel template and studies critically appraised using a modified version of the MetaQAT tool, with resolution of disagreements by consensus. Findings were narratively synthesised.

\section{Results}

61 articles were included. Almost all studies used observational designs, were hospital-based, and the majority had important limitations. Symptomatic adult COVID-19 cases consistently show peripheral T cell lymphopenia, which positively correlates with increased disease severity, duration of RNA positivity, and non-survival; while asymptomatic and paediatric cases display preserved counts. People with severe or critical disease generally develop more robust, virusspecific $T$ cell responses. T cell memory and effector function has been demonstrated against multiple viral epitopes, and, cross-reactive $\mathrm{T}$ cell responses have been demonstrated in unexposed and uninfected adults, but the significance for protection and susceptibility, respectively, remains unclear.

\section{Interpretation}

A complex pattern of T cell response to SARS-CoV-2 infection has been demonstrated, but inferences regarding population level immunity are hampered by significant methodological limitations and heterogeneity between studies. In contrast to antibody responses, populationlevel surveillance of the cellular response is unlikely to be feasible in the near term. Focused evaluation in specific sub-groups, including vaccine recipients, should be prioritised. 
medRxiv preprint doi: https://doi.org/10.1101/2020.08.24.20180679; this version posted August 29, 2020. The copyright holder for this preprint (which was not certified by peer review) is the author/funder, who has granted medRxiv a license to display the preprint in perpetuity.

It is made available under a CC-BY-NC-ND 4.0 International license .

\section{INTRODUCTION}

Severe Acute Respiratory Syndrome Coronavirus 2 (SARS-CoV-2), the novel pathogen causing coronavirus disease 2019 (COVID-19), has spread globally and was declared a pandemic by the World Health Organization (WHO) on 11th March 2020. ${ }^{1}$ At the time of writing, there have been around $22.3 \mathrm{~m}$ confirmed cases and 782,456 deaths reported to the WHO. ${ }^{2}$ Lack of preexisting immunity to this novel and highly infectious betacoronavirus is likely to be responsible for the extraordinary surge in cases worldwide.

There has been an unparalleled global effort to characterise the immune response to SARSCoV-2 infection, and to develop and test vaccine candidates at unprecedented speed. Understanding the patterns in individual- and population-level immunity will be key to informing future decisions on implementation of non-pharmacological interventions, broader public health policies, and strategies for vaccine delivery.

While there is a rapidly growing body of literature on the antibody response to SARS-CoV-2, much less has been published on the cellular immune response, despite its critical importance in antiviral immunity and vaccine development.

There are principally three areas of interest; firstly, the role of $\mathrm{T}$ cells in viral control and immunopathogenesis during acute SARS-CoV-2 infection; secondly the role of $T$ cells in establishing durable protective immunity against reinfection; finally, the relevance of pre-existing cross-reactive cellular immunity from endemic human coronaviruses (HCoV), or SARS-CoV-1. ${ }^{3}$

This paper focuses on summarising current understanding of the cellular response to SARSCoV-2 infection, specifically exploring the role that $\mathrm{T}$ cell-mediated immunity might play in resistance to severe infection, clinical and virological recovery, and long-term protection - while recognising the dynamic interdependence of the two arms of the adaptive immune response. It is the second of two linked papers ${ }^{4}$ summarising results from a wide-ranging systematic review of peer-reviewed and pre-print literature on the human adaptive immune response to SARSCoV-2 infection. 
medRxiv preprint doi: https://doi.org/10.1101/2020.08.24.20180679; this version posted August 29, 2020. The copyright holder for this preprint (which was not certified by peer review) is the author/funder, who has granted medRxiv a license to display the preprint in perpetuity.

It is made available under a CC-BY-NC-ND 4.0 International license .

\section{METHODS}

A systematic review was carried out according to the Preferred Reporting Items for Systematic Reviews and Meta-Analyses (PRISMA) guidelines. The protocol was pre-registered with PROSPERO (CRD42020192528).

\section{Identification of studies}

Keyword-structured searches were performed in MEDLINE, Embase, COVID-19 Primer and the Public Health England library ${ }^{5}$ for articles published between 01/01/2020-26/06/2020. A sample search strategy can be found in Supplementary Appendix A. We also consulted subject area experts to identify relevant papers not captured through the database searches.

\section{Definitions, inclusion and exclusion criteria}

We included studies in all human and animal populations, and carried out in all settings (laboratory, community and clinical - encompassing primary, secondary and tertiary care centres), relevant to our research questions. We excluded case reports, commentaries, correspondence pieces or letter responses, consensus statements or guidelines and study protocols. We included studies reporting on any aspect of the $T$ cell response, irrespective of follow-up duration, and on correlates of that response. We defined "correlates" to include (among others) age; gender; ethnicity; the presence of intercurrent or co-morbid disease e.g. diabetes, cardiovascular, chronic respiratory disease; and primary illness severity, proxied by the WHO's distinction between "mild", "moderate", "severe" and "critical" COVID-19, ${ }^{6}$ or by requirement for intensive care.

\section{Selection of studies}

Studies were independently screened on title, abstract and full text by two team members (working across four pairs), and disagreements arbitrated by one of the review leads.

Data extraction, assessment of study quality, and data synthesis

Data were extracted in duplicate from each included study into a dedicated Microsoft Excel template (Supplementary Appendix B). Pre-prints of subsequently published peer reviewed papers were included, and results extracted where substantial differences in reported data were identified; if little difference was found, only the peer-reviewed version was retained. 
Critical appraisal for each included study was performed in duplicate using a version of the MetaQAT 1.0 tool that was adapted for improved applicability to the basic science and laboratory-based studies that are common in this field. ${ }^{7}$ The adapted MetaQAT tool was used to gather both qualitative feedback on study quality, and scaled responses (yes/no/unclear) to questions around study reliability, internal and external validity, and applicability, in turn converted into weighted scores for each paper. Accordingly, studies were assigned a "high", "medium" or "low" quality grading. Full details of this process can be found in Supplementary Appendix C.

Due to the degree of methodological heterogeneity across included studies, formal metaanalysis was not performed. Results are synthesised narratively in the sections that follow.

\section{RESULTS}

\section{Descriptive overview of included studies:}

A total of 9,223 records were identified through searches conducted for the review after deduplication, and a further five through expert consultation, of which 61 papers were included (see PRISMA flowchart in figure 1).

Key characteristics of included studies are further summarised in table 1. Of the included reports, $34(58 \%)$ were peer-reviewed journal papers. The most common designs were casecontrol $(n=26,43 \%)$ and cohort $(n=22,36 \%)$, with 50 studies (82\%) considering human participants sampled from hospital settings, and most originating from China $(n=32,52 \%)$. Only five studies (8\%) specifically examined cellular responses in children; while only one study examined differences by gender, and none by ethnicity (see table 2). Most studies were rated of medium quality (n-44, $72 \%$ ), with ten (16\%) achieving a high-quality rating.

\section{Acute phase $\mathrm{T}$ cell response and association with cytokine release syndrome}

\section{General features of the $T$ cell response in the acute phase}


medRxiv preprint doi: https://doi.org/10.1101/2020.08.24.20180679; this version posted August 29, 2020. The copyright holder for this preprint (which was not certified by peer review) is the author/funder, who has granted medRxiv a license to display the preprint in perpetuity. It is made available under a CC-BY-NC-ND 4.0 International license .

The majority of included papers commented on general aspects of the cellular response to SARS-CoV-2 infection in the acute phase of illness, though the duration of this period was not explicitly defined. Methods used to quantify the $T$ cell response varied between studies; for example, Laing et al partnered a total lymphocyte count from a full blood count and flow cytometry to derive estimates of absolute $\mathrm{T}$ cell subset counts based on the gated percentages, while other studies used direct quantification of lymphocyte subsets, such as TruCount ${ }^{\mathrm{TM}}$ and Flow-Count ${ }^{\mathrm{TM}}$ Fluorosphere technology.

Higher quality studies consistently found evidence for reduction of total peripheral T cell counts in symptomatic adult patients during the acute phase, often accompanied by increased activation of remaining T cells and evidence of functional 'exhaustion', as defined by expression of the markers PD-1 and Tim-3; however findings regarding specific subsets were more mixed. Three well-designed cohort studies ${ }^{8-10}$ showed reductions in both $\mathrm{CD}^{+}$and $\mathrm{CD} 8^{+} \mathrm{T}$ cell counts in clinical cohorts ranging in size from 30 to 187 patients, while two found evidence of greater reductions in $\mathrm{CD}^{+}$(cytotoxic) than $\mathrm{CD}^{+}$(helper) T cells. ${ }^{8,9}$ A cohort study ( $\mathrm{n}=17$ patients) only found evidence of reduction in $\mathrm{CD}^{+}$but not $\mathrm{CD}^{+} \mathrm{T}$ cell counts on comparing patients with 'aggravated' (or clinically progressive) with non-aggravated disease. ${ }^{11}$ A cohort study of 64 patients from Italy showed that $\mathrm{T}$ cell frequencies were maintained in patients with mild and asymptomatic disease. $^{12}$ Broadly similar findings emerge from a range of high-quality casecontrol studies, typically with much larger sample sizes. Three hospital-based case-control studies with sample sizes ranging from 102 to 522 patients found evidence of globally reduced lymphocyte counts $\left(\mathrm{CD}^{+}, \mathrm{CD} 4^{+}\right.$and $\mathrm{CD} 8^{+} \mathrm{T}$ cells) in the acute phase. ${ }^{13-15}$ These findings were also reflected in two summary reviews.,16 The first, a medium-quality meta-analysis incorporating data on 5,912 patients across 35 published/pre-print reports, showed that total numbers of $B$ cells, $T$ cells and natural killer (NK) cells were all significantly decreased in COVID-19 patients' peripheral blood. ${ }^{16}$ This picture of peripheral T cell lymphopenia in COVID19 patients is reinforced by findings from a larger body of medium- to low-quality observational

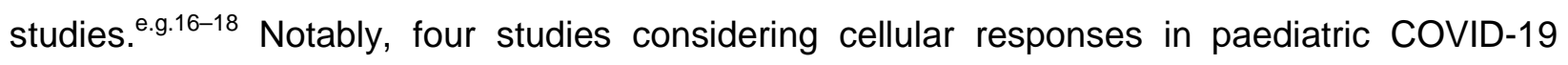
cases universally demonstrated comparable $\mathrm{T}$ cell counts to healthy paediatric controls, or higher counts when compared against adult cases. ${ }^{19-21}$ The one study to evaluate responses in asymptomatic adult cases $(n=20)$ found little change in the circulating $T$ cell counts within this group also. $^{12}$ 
medRxiv preprint doi: https://doi.org/10.1101/2020.08.24.20180679; this version posted August 29, 2020. The copyright holder for this preprint (which was not certified by peer review) is the author/funder, who has granted medRxiv a license to display the preprint in perpetuity.

It is made available under a CC-BY-NC-ND 4.0 International license .

Five studies provided more detailed analysis of $\mathrm{T}$ cell phenotypes in severe and/or critical disease. ${ }^{12,22-25}$ A high-quality study by Anft et al. $(n=53)$ found significant peripheral depletion in

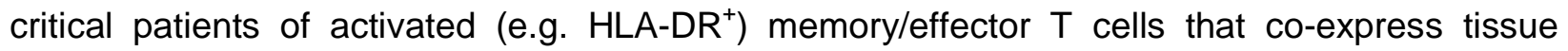
migratory markers (e.g. CD11a), when compared to severe and moderate cohorts. ${ }^{22}$ Lower frequencies of terminally differentiated T-cell subsets (TEMRA) were found in patients with both severe and critical disease. Importantly, recovery from acute respiratory distress syndrome

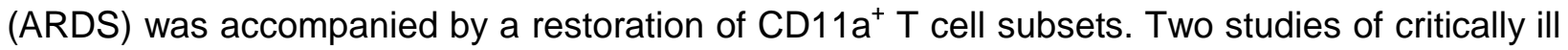
patients identified stronger inflammatory cytokine $\mathrm{T}$ cell responses to spike protein, ${ }^{22}$ and to spike, membrane and nucleocapsid proteins, with greater reactivity by CD4 ${ }^{+}$compared to CD8 ${ }^{+}$ cells ${ }^{23}$ within this group, respectively. Carsetti et al. reported an overall increase in activated (e.g. $\left.\mathrm{HLA}^{-D R^{+}}\right) \mathrm{CD}^{+} \mathrm{T}$ cells in 16 patients across both mild and severe disease but found that $\mathrm{HLA}_{-D \mathrm{R}^{+}} \mathrm{CD}^{+}$cells were specifically increased in severe disease. ${ }^{12}$ Two studies also found increased numbers of activated T cells in patients with severe and critical disease, with reversal upon disease remission. ${ }^{24,25}$

Accompanying $\mathrm{T}$ cell dysregulation, a cytokine release syndrome (CRS)-like clinical picture occurs in many patients with severe SARS-CoV-2 infection. ${ }^{26}$ Elevated levels of many proinflammatory cytokines, such as IL-6, and to lesser degree, IL-10, and TNF-a were identified in patients in four studies. ${ }^{3,27-29}$ Concentrations of pro-inflammatory cytokines such as IL-6 positively correlated to severity of disease and with lymphopenia. ${ }^{9,13,16,17,24,30-36}$ A large peerreviewed study with 1,018 participants reported over ten-fold increases in IL-6 levels amongst COVID-19 cases, and found that serum IL-6 >20pg/mL was strongly associated with inhospital mortality (OR 9.78, $\mathrm{p}<0.001$ ) on an adjusted multivariable regression analysis. ${ }^{36} \mathrm{~A}$ preprint systematic review reported 1.93-fold increases in IL-6 and 1.55-fold increases in IL-10 for severe patients. ${ }^{16}$ In line with this, another large study $(n=548)$ reported significantly increased IL-6 levels in non-survivors compared with survivors. ${ }^{34}$ Correspondingly, levels of IL-6 and IL-10 appeared to be negatively correlated with total $\mathrm{T}$ cell and subset counts across all included studies, and showed normalisation in tandem with clinical resolution. ${ }^{13}$ Findings for IL-1, IL-2, IL-4 and IL-8 were more mixed. ${ }^{13,16,24,32,33,35,37}$

\section{Dynamics of the $T$ cell response over time during the acute phase}

Seven studies reported longitudinal data on the cellular response, mostly focusing on withinhospital trends, with a maximum follow-up range of 14-44 days following symptom 
medRxiv preprint doi: https://doi.org/10.1101/2020.08.24.20180679; this version posted August 29, 2020. The copyright holder for this preprint (which was not certified by peer review) is the author/funder, who has granted medRxiv a license to display the preprint in perpetuity.

It is made available under a CC-BY-NC-ND 4.0 International license .

onset. $^{10,14,17,32,38-40}$ Two large high-quality case-control studies $(n=103$ and $n=187)$ found that low $T$ cell counts on admission increased steadily over the course of admission. Subsequent recovery of lymphocyte count was roughly consistent with clinical improvement. ${ }^{10,14}$ One study found evidence of significant decreases in counts of $\mathrm{CD}^{+} \mathrm{T}, \mathrm{CD} 4^{+} \mathrm{T}, \mathrm{CD} 8^{+} \mathrm{T}$, and NK cells in COVID-19 patients compared with healthy controls (all $\mathrm{p}<0.05$ ) on admission. In a subset of $\mathrm{n}=23$ patients followed up two weeks after initial presentation, those with newly negative PCR results showed the most dramatic recoveries in T cell subset counts. ${ }^{14}$ Two studies reported longitudinal trends in detail at regular follow-up intervals; the first, a cohort study from Italy involving 18 patients (nine mild and nine severe cases), found that low total lymphocyte counts in severe cases were stably maintained for up to 20 days post-admission, with little discernible difference between T cell subsets. ${ }^{17}$ The second, a French cohort study $(n=15)$ of predominantly elderly patients admitted to intensive care, found that $\mathrm{CD} 8^{+}$counts fell to their lowest value by days 11-14 after symptom onset $(p=0.03)$, with recovery thereafter, but noted a slightly later nadir for $\mathrm{CD}^{+}$(days 19-23) and with no significant change in the overall CD4/CD8 ratio throughout the 35 -day follow-up period. ${ }^{39}$

\section{Correlates of the $\mathrm{T}$ cell response}

The number of studies addressing demographic and clinical correlates of the cellular response was small and many potentially important variables such as ethnicity were not addressed. Key findings from this literature are summarised in table 2. The largest single body of work examined relationships between $T$ cell response and disease severity, based predominantly on studies in the hospital setting. Definitions of clinical severity employed in these studies were variable (most as per WHO, however some were based on Chinese national guidance).

\section{Viral cross-reactivity of T cells}

Eight studies explored cross-reactivity of T cells between SARS-CoV-2 and related human coronaviruses within small adult-only cases and controls. ${ }^{41-48}$. Using activation-induced marker assays, Grifoni et al. detected SARS-CoV-2-reactive CD4 ${ }^{+} \mathrm{T}$ cells against a range of spike and non-spike epitopes in 12/20 pre-pandemic US donors ${ }^{42}$ while Weiskopf et al reported low levels of cross-reactivity in only 2/10 pre-pandemic German donors. ${ }^{48}$ Using IFN-y ELISpot, Gallais et 
medRxiv preprint doi: https://doi.org/10.1101/2020.08.24.20180679; this version posted August 29, 2020. The copyright holder for this preprint (which was not certified by peer review) is the author/funder, who has granted medRxiv a license to display the preprint in perpetuity.

It is made available under a CC-BY-NC-ND 4.0 International license .

al found some $T$ cell cross-reactivity mainly to the S2-domain in 5/10 pre-pandemic French donors $^{41}$ and Le Bert et al found T cells specific to nucleocapsid protein (NP) and non-structural proteins 7 and 13 (NSP7, NSP13) in SARS-CoV-1/2 unexposed donors. ${ }^{43}$ The latter Singaporebased study also reported robust SARS-CoV-2 NP-reactivity in T cells from SARS-CoV-1 convalescents, with these memory cells persisting for 17 years after the SARS outbreak. ${ }^{43}$

Amongst controls recruited during the pandemic, but confirmed as antibody- and PCR-negative, spike-reactive T cells were demonstrated in 23/68 controls in a high-quality German study; ${ }^{44}$ and in 12/14 controls in a medium-quality Russian study, including one household contact of a COVID-19 case. The latter study also included a smaller group of pre-pandemic donors $(n=10)$, who had significantly lower frequency and magnitude of reactivity than the controls recruited during the pandemic, hinting at a possible protective effect of cross-reactive $\mathrm{T}$ cells. ${ }^{45}$ In contrast, Peng et al. found no SARS-CoV-2-specific T cell responses in either pre-pandemic or during-pandemic antibody-negative UK controls $(n=19) .{ }^{46}$

Notably, studies consistently found a lower frequency and magnitude of T cell response as well as a differential pattern of immunodominance in reactive unexposed controls relative to SARSCoV-2 convalescents, with low homology between COVID-19 convalescent T cell epitopes and known epitopes from other HCoV. Interestingly, an Australian study found that frequencies of $\mathrm{T}$ follicular helper (TFH) cells specific to HCoV-HKU1 were higher amongst COVID-19 convalescents $(n=41)$ than uninfected controls $(n=27)$, suggesting boosting of HKU1-specific responses following SARS-CoV-2 exposure, and hinting at a coronavirus-specific TFH response. $^{47}$

\section{Characterisation of T-cell subpopulations and protective immunity}

Twelve studies characterised T-cell subpopulations, including magnitude, functionality and phenotypic characteristics, post-acute COVID-19 infection. Timing of sampling differed both within and between studies (supplementary appendix D). One French contact-tracing study demonstrated SARS-CoV-2-specific $\mathrm{T}$ cell responses against structural (spike, membrane, nucleocapsid) and accessory proteins in all nine index cases, in samples collected at 47-69 days post symptom-onset, as well as in 6/8 PCR-negative or untested contacts (of whom five were symptomatic), in samples collected up to 80 days post-onset. ${ }^{41}$ A UK-based study of 
medRxiv preprint doi: https://doi.org/10.1101/2020.08.24.20180679; this version posted August 29, 2020. The copyright holder for this preprint (which was not certified by peer review) is the author/funder, who has granted medRxiv a license to display the preprint in perpetuity.

It is made available under a CC-BY-NC-ND 4.0 International license .

COVID-19 convalescents (28 mild cases, 14 severe cases) characterised the $T$ cell response using IFN-y ELISpot assays on samples taken at least 28 days post symptom onset. ${ }^{46} \mathrm{~A}$ strong and broad SARS-CoV-2-specific $T$ cell response was generally elicited but varied between individuals. T cell response breadth $(p=0.010)$ and magnitude $(p=0.002)$ were significantly higher in patients who recovered from severe disease in comparison to mild cases. Sub-set evaluation demonstrated $\mathrm{CD}^{+} \mathrm{T}$ cells mediated a greater proportion of responses detected to spike and membrane (M) or NP epitopes. No difference in the levels of polyfunctional T cells was observed between mild and severe disease. Differences were observed in the cytokine profiles of $\mathrm{CD}^{+} \mathrm{T}$ cells targeting different viral antigens, with the M/NP-specific CD8 ${ }^{+} \mathrm{T}$ cells displaying wider functionality compared to those targeting spike protein $(p=0.0231)$. In those with mild disease, M/NP-specific $\mathrm{CD}^{+} \mathrm{T}$ cells were significantly higher than spike-specific $\mathrm{T}$ cells. This trend was not observed in those with severe disease. ${ }^{46}$

These findings complement the study by Grifoni et al (discussed above) which found that NP, M and spike contain the immunodominant epitopes for both $\mathrm{CD}^{+}$and $\mathrm{CD}^{+} \mathrm{T}$ cells. $^{42}$ No significant differences in the cytotoxic potential was detected between mild and severe disease. Specific SARS-CoV-2-reactive T cells were not frequently observed in healthy, unexposed individuals. Furthermore, the magnitude of T cell responses in COVID-19 patients correlated with related antibody titres (anti-spike, anti-RBD and anti-NP). Another study stimulated peripheral blood mononuclear cells (PBMCs) from 18 COVID-19 patients ranging in disease severity with two overlapping peptide pools spanning the full spike region. ${ }^{44}$ Twelve patients had detectable $\mathrm{CD}^{+} \mathrm{T}$ cell reactivity against the first peptide pool, which contained $\mathrm{N}$-terminal epitopes including the RBD. Fifteen patients displayed reactive CD4 ${ }^{+} \mathrm{T}$ cells against the second peptide pool, which contained C-terminal epitopes processing higher homology with HCoVs. Among the non-reactive cases most had critical disease. ${ }^{44}$

Le Bert et al assayed peripheral blood T cell responses to NP and NSP7 and NSP13 of the large SARS-CoV-2 proteome using an IFN-y ELISPOT assay. Samples were obtained from 24 individuals who had experienced mild to severe COVID-19. For all patients, IFN-Y spots were observed following stimulation with NP peptide and nearly all displayed responses against multiple regions of NP. A further sub-analysis demonstrated $\mathrm{T}$ cell recognition of multiple regions of SARS-CoV-2 NP among recovered patients (8/9). ${ }^{43}$ 
medRxiv preprint doi: https://doi.org/10.1101/2020.08.24.20180679; this version posted August 29, 2020. The copyright holder for this preprint (which was not certified by peer review) is the author/funder, who has granted medRxiv a license to display the preprint in perpetuity. It is made available under a CC-BY-NC-ND 4.0 International license .

Six studies reported on the phenotypic and target profile of T cell subsets. One study performed an in-depth characterisation of humoral and cellular immunity against the spike protein in samples taken from 41 adults who had recovered from mild-moderate SARS-CoV-2 infection (five requiring hospitalisation but not mechanical ventilation) and 27 controls. Expanded populations of spike-specific memory B cells and circulating (c)TFH cells (which play a critical role in supporting antigen-specific $B$ cells to initiate and maintain humoral immune responses) were detected. ${ }^{47}$ The frequencies of unstimulated cTFH cells were comparable between SARSCoV-2 convalescent and uninfected groups. In general, robust cTFH cells activity to the SARSCoV-2 spike protein was observed among the convalescent group, whereas responses to RBDspecific cTFH were significantly lower $(p<0.0001)$. The antigen reactivity of spike-specific noncTFH CD4 memory $\left(C D 3^{+} C D 4^{+} C D 45 R A{ }^{-} C X C R 5\right)$ cells revealed similar trends with strong recognition of SARS-CoV-2 and smaller frequencies of RBD-specific $T$ cells. High plasma neutralisation activity was also found to be associated with increased spike-specific antibody, but notably also with the relative distribution of spike-specific cTFH subsets. ${ }^{47}$

Another study analysed the cellular response in samples taken from 31 COVID-19 patients, none of whom required intensive care or oxygen supplementation. A central memory phenotype $\left(\mathrm{CD} 45 \mathrm{RO}^{+}, \mathrm{CCR} 7^{+}\right)$, followed by an effector memory phenotype (CD45RO+, CCR7') were predominate within the spike-protein reactive $\mathrm{CD}^{+} \mathrm{T}$ cell population. An effector memory, followed by the terminal effector cells (CD45RO-, CCR7-) were the predominant phenotypes among antigen-specific CD8 ${ }^{+} \mathrm{T}$ cells. A significant increase in activated (CD38 $\left.{ }^{+}, \mathrm{HLA}^{-} \mathrm{DR}{ }^{+}\right) \mathrm{CD}^{+}$ $\mathrm{T}$ cells was detected among cases. Further $\mathrm{T}$ cell response characterisation showed $\mathrm{CD} 4^{+}$and $\mathrm{CD}^{+} \mathrm{T}$ cell activation in response to full-length $\mathrm{S}$-protein exposure, and the M-protein response was significantly stronger $(\mathrm{p}=0.0352)$. A "mild" correlation between the magnitude of T-cell and humoral responses was reported (anti-RBD $\lg G$ and $C D 8^{+} T$-cell response $r=0.386 p=0.0321$ ), whereas an interdependence was observed between the magnitude of $\mathrm{CD}^{+}$and $\mathrm{CD}^{+}$ responses ( $r$ and $p$ values not presented). ${ }^{45}$. Minervina and colleagues reported detection of $T$ cell clones within both the effector and central memory subpopulations, in samples obtained from two returnees from countries with high SARS-CoV-2 transmission. ${ }^{49}$ Similarly, Weiskopf et al, in their study of 10 COVID-19 patients who developed ARDS, reported that peripheral SARSCoV-2-specific CD4 ${ }^{+}$T-cells typically had a central memory phenotype (based on CD45RA and CCR7 expression), whereas the majority of virus-specific CD8 ${ }^{+}$T-cells had a CCR7- effector memory (TEM) or TEMRA phenotype. ${ }^{48}$ In contrast, a study of four COVID-19 positive paediatric cases with mild disease, and five uninfected controls, found no difference in the 
medRxiv preprint doi: https://doi.org/10.1101/2020.08.24.20180679; this version posted August 29, 2020. The copyright holder for this preprint (which was not certified by peer review) is the author/funder, who has granted medRxiv a license to display the preprint in perpetuity.

It is made available under a CC-BY-NC-ND 4.0 International license .

effector or central memory phenotypes of the $\mathrm{CD}^{+}$and $\mathrm{CD}^{+}$populations compared with controls. $^{21}$

A small study conducted a phenotypic analysis of circulating SARS-CoV-2-specific T cells in samples obtained 20-47 days post positive PCR from individuals recently recovered from mild SARS-CoV-2 infection. The analysis was conducted using combination SARS-CoV-2-specific T cell detection with CyTOF. IFN-y producing spike-specific $\mathrm{CD}^{+}$and $\mathrm{CD}^{+} \mathrm{T}$ cells were detected, suggestive of a spike-specific Th1 response, where as Th2 and Th17 lineages were not detected among spike-specific CD4 ${ }^{+}$T cells. $^{50}$

Evidence of potential protective T cell mediated immunity is provided by one US-based study that measured the cellular response in rhesus monkeys ( $n=9$ cases, $n=3$ controls) upon repeat challenge with pooled spike peptides. Based on IFN-Y ELISpot assays, cellular immune responses were observed in the majority of animals, with a trend toward lower responses in the lower dose groups. Intracellular cytokine staining assays demonstrated induction of both spikespecific $\mathrm{CD}^{+}$and $\mathrm{CD}^{+} \mathrm{T}$ cell responses. Post re-challenge, very limited viral RNA was observed in bronchoalveolar lavage (BAL) on day one following re-challenge in three animals, with no viral RNA detected at subsequent timepoints. In contrast, high levels of viral RNA were observed in the concurrently challenged naive animals. However, these findings to do not exclude the possibility that protection was antibody dependent rather than due to $\mathrm{T}$ cell immunity exclusively. ${ }^{51}$

\section{DISCUSSION}

\section{Summary of key findings}

Acutely, adult COVID-19 patients exhibit a depletion of T cells in the peripheral blood, the extent of which is positively correlated with disease severity, whereas asymptomatic patients and children tend to have preserved peripheral $\mathrm{T}$ cell counts. This suggests an important relationship between pathogenesis and the circulating $\mathrm{T}$ cell pool. It has been speculated that children may receive protection from a diverse naive $T$ cell repertoire, with adults of increasing age at higher risk due to immunosenescence. ${ }^{52}$ Unfortunately, few studies have explored the relationship between T cells, age and clinical severity, with appropriate statistical adjustment. There is also emerging evidence of an important role for the over-production of cytokines - in 
medRxiv preprint doi: https://doi.org/10.1101/2020.08.24.20180679; this version posted August 29, 2020. The copyright holder for this preprint (which was not certified by peer review) is the author/funder, who has granted medRxiv a license to display the preprint in perpetuity.

It is made available under a CC-BY-NC-ND 4.0 International license .

particular IL-6 - in immunopathogenesis within COVID-19, however, drivers of these observed changes remain poorly understood.

Although less comprehensive, longer-term data suggest that $\mathrm{T}$ cell reductions are transient, with rapid recovery of counts within days to weeks of clinical recovery and PCR negativity. This supports the hypothesis that $\mathrm{T}$ cells are sequestered rather than destroyed, although the observation of similarly depleted T cell numbers in the BAL samples of severe patients indicates that $\mathrm{T}$ cells are not simply recruited en masse to infected tissues. ${ }^{53}$

In the context of well-recognised variations in COVID-19 clinical outcomes by age, ethnicity and co-morbid status, there is a striking shortage of robust evidence on demographic and clinical correlates of the cellular response to SARS-CoV-2. We identified a single study considering gender-related effects on T cells, and eight studies considering cellular responses with age (a majority of these in paediatric patients with or without adult controls). We identified no studies evaluating other potentially important determinants, including ethnicity.

Evidence characterising cellular immune responses suggest enduring $\mathrm{T}$ cell immunity, with phenotypic profiles consistent with helper and memory $\mathrm{T}$ cell functions and evidence of activity against multiple viral targets. Variation in viral targets is observed between disease severity and, based on one study, the breadth and magnitude of the T cell response were significantly higher in patients who recovered from severe compared to mild disease. Responses were also detected in individuals who experienced mild infection. However, this evidence derives from small, observational studies conducted on samples taken at varying time points from individuals, with selection criteria rarely described. The longevity of this T cell immunity and the degree of protection it provides remains unknown.

\section{Strengths and limitations of the study}

This study is the first to systematically evaluate and critically appraise the published literature on the $\mathrm{T}$ cell immune response to SARS-CoV-2, more than eight months since it has emerged. Formative reviews of evidence on the immune response are narrative with few exceptions, or focus on specific aspects. ${ }^{16,54}$ Our review is broader in scope and comprehensiveness.

Limitations arise from the methodology applied, and from the nature of the underlying evidence. First, while the search strategy was broad in choice of keywords and inclusion of pre-print 
medRxiv preprint doi: https://doi.org/10.1101/2020.08.24.20180679; this version posted August 29, 2020. The copyright holder for this preprint (which was not certified by peer review) is the author/funder, who has granted medRxiv a license to display the preprint in perpetuity.

It is made available under a CC-BY-NC-ND 4.0 International license .

publications, it is possible that some results were missed, particularly on pre-print servers for which structured searches are more challenging. Additional limitations arise from the nature of the underlying evidence base on which this review draws. Variations in reporting practice present major challenges for critical appraisal and weighting of evidence. For example, narrative reviews - popular in this field - have limited methods reporting. Further difficulty is introduced through the varying treatment protocols employed, clinical severity and case definitions, and varying methods adopted for $\mathrm{T}$ cell counts, functionality, phenotypes, and assay validation. These considerations are critical to study T cell immunity to SARS-CoV-2 as the assays are evolving and yet to be formally validated and standardised. Thirdly, many of the studies have important methodological limitations, notably; small sample sizes, minimal reporting on participation selection and reasons for follow-up, non-blinding, and widespread lack of statistical analysis that control for confounders.

\section{Policy and practice implications}

Many unanswered questions remain, such as the durability of and protection afforded by virusspecific $\mathrm{T}$ cell responses, and their relative importance in protection from reinfection compared with antibodies. More data is also needed on correlates of $\mathrm{T}$ cell responses and the potential of cross-reactive cellular immunity.

An important application of findings from cellular response studies will be towards the development, evaluation, and implementation of SARS-CoV-2 vaccines. In parallel with emerging data from COVID-19 patients, vaccine developers have begun to report on cellular immunogenicity from early phase evaluations, though this is notably lacking from the pre-print Phase 2 trial report of Sinovac's inactivated vaccine. ${ }^{55}$ Other candidates including Moderna's mRNA-1271, Oxford University's ChAdOx1 nCoV-19, and CanSino's Ad5 vaccines, have demonstrated $T$ cell responses against S-proteins. Responses for the CanSino candidate were limited, however, by likely pre-existing immunity to the human adenovirus 5 vector. Furthermore, unlike for the second dose of Moderna's mRNA vaccine, cellular responses were not boosted after a second dose of Oxford's chimpanzee adenovirus-vectored vaccine. ${ }^{56-58}$ While there is an understandable demand for candidates able to provide protection with a single dose, vaccines which allow boosting of cellular responses may better mimic natural immunity against endemic coronaviruses. It is also worth considering whether spike -focused platforms will be able to fully harness the cellular response potential, or whether traditional inactivated whole-virus and novel 
medRxiv preprint doi: https://doi.org/10.1101/2020.08.24.20180679; this version posted August 29, 2020. The copyright holder for this preprint (which was not certified by peer review) is the author/funder, who has granted medRxiv a license to display the preprint in perpetuity.

It is made available under a CC-BY-NC-ND 4.0 International license .

virus-like particle platforms, which provide a fuller range of epitopes, will be necessary to build durable, protective immunity across populations. It will be important to evaluate vaccine efficacy in groups with high prevalence of previous exposure or infection, such as health and care staff, who will be a priority group following licensure. In addition to antibody testing, baseline assessments of virus-specific $\mathrm{T}$ cell reactivity are likely to be highly useful for this purpose.

Current estimates of population immunity rely solely on seroprevalence studies, however in the context of evidence for cellular responses in seronegative exposed individuals, and the apparent waning of antibody responses over time, current surveillance methods are likely to be underestimating both exposure and immunity. A more developed understanding of the role of $\mathrm{T}$ cells in long-term protection will be helpful to policy makers in terms of modelling where population-level immunity lies and informing long-term surveillance and immunisation strategies. However, by contrast with antibody testing - a mainstay of immune surveillance for many communicable diseases - existing $\mathrm{T}$ cell assays are difficult to standardise and hard to scale, therefore unlikely to be deliverable at population level within the timeframe of the SARS-CoV-2 pandemic. In the short-term, emphasis may need to be placed on determining the utility of $T$ cell assays to guide clinical and public health actions at the individual level, particularly in patients with immunosuppression, or those at the extremes of age. In parallel, adequately powered and controlled studies providing deep immunophenotyping of T cells, B cells, and comprehensive characterisation of immune responses in mild or asymptomatic cases, and in vaccine recipients, will yield insights about the interdependence and relative importance of cellular and humoral responses. Over the long-term, development of scalable T cell assays may help to strengthen population immune surveillance systems.

\section{Conclusions}

A complex picture is emerging concerning the cellular immune response to SARS-CoV-2 infection, including the interplay between compartments of the immune systems, and the balance between protective versus pathological responses. Inferences are limited by methodological limitations within studies, and heterogeneity between studies. Evaluation of cellular responses at scale is currently infeasible and the benefits as yet unclear. Findings from targeted testing may carry important clinical and policy implications for public health interventions within at-risk sub-groups, for understanding mechanisms of vaccine efficacy, and for informing long-term population immunisation and surveillance strategies. 
medRxiv preprint doi: https://doi.org/10.1101/2020.08.24.20180679; this version posted August 29, 2020. The copyright holder for this preprint (which was not certified by peer review) is the author/funder, who has granted medRxiv a license to display the preprint in perpetuity.

It is made available under a CC-BY-NC-ND 4.0 International license. 
medRxiv preprint doi: https://doi.org/10.1101/2020.08.24.20180679; this version posted August 29, 2020. The copyright holder for this preprint (which was not certified by peer review) is the author/funder, who has granted medRxiv a license to display the preprint in perpetuity.

It is made available under a CC-BY-NC-ND 4.0 International license .

\section{Author contributions (CRediT author statement)}

MS - investigation, writing - original draft, writing - review and editing

MCIvS - conceptualisation, investigation, methodology, writing - original draft, writing - review and editing

NP - investigation, writing - original draft, writing - review and editing

DE - conceptualisation, investigation, project administration, writing - original draft, writing review and editing

$\mathrm{CH}$ - investigation, writing - original draft, writing - review and editing

$\mathrm{DL}$ - investigation, writing - review and editing

SR - investigation, writing - review and editing

SVW - investigation, writing - review and editing

WHB - validation, writing - review and editing

PK - conceptualisation, validation, writing - review and editing

$\mathrm{JM}$ - validation, writing - review and editing

AMS - validation, writing - review and editing

GA - conceptualisation, supervision, validation, writing - review and editing

SJP - conceptualisation, supervision, validation, writing - review and editing

SAI - conceptualisation, investigation, methodology, project administration, writing - original draft, writing - review and editing

\section{Acknowledgements}

We thank Professor Mike Ferguson from the School of Life Sciences, University of Dundee, for comments on the research questions and initial outputs from this work; and Professor Mark Petticrew from the Faculty of Public Health and Policy, London School of Hygiene and Tropical Medicine for advice on methodological aspects of this study.

\section{Funding}

This research did not receive any specific grant from funding agencies in the public, commercial or not-for-profit sectors. MCIvS is funded by a NIHR Doctoral Fellowship (Ref NIHR300156). JM acknowledges the support of the National Institute for Health Research (NIHR) Biomedical Research Centre based at Guy's and St Thomas' NHS Foundation Trust and King's College London. SAI is supported by a Wellcome Trust Clinical Research Training Fellowship (Ref No $215654 / Z / 19 / Z)$. The views expressed in this paper are those of the authors and not necessarily those of the NHS, the NIHR, PHE or the Department of Health. 
medRxiv preprint doi: https://doi.org/10.1101/2020.08.24.20180679; this version posted August 29, 2020. The copyright holder for this preprint (which was not certified by peer review) is the author/funder, who has granted medRxiv a license to display the preprint in perpetuity.

It is made available under a CC-BY-NC-ND 4.0 International license.

\section{Competing interests}

JM is chief scientific officer, shareholder and scientific founder of Leucid Bio, a spinout company focused on development of cellular therapeutic agents. The authors report no other competing financial interests or conflicts of interest.

\section{Ethics}

This was a systematic review based on analysis of openly published secondary data. No ethical approval was required. 
medRxiv preprint doi: https://doi.org/10.1101/2020.08.24.20180679; this version posted August 29, 2020. The copyright holder for this preprint (which was not certified by peer review) is the author/funder, who has granted medRxiv a license to display the preprint in perpetuity.

It is made available under a CC-BY-NC-ND 4.0 International license .

\section{REFERENCES}

1. WHO. COVID-19 timeline. https://www.who.int/news-room/detail/29-06-2020covidtimeline. Published 2020. Accessed August 20, 2020.

2. WHO. WHO Coronavirus Disease (COVID-19) Dashboard. https://covid19.who.int/. Published 2020. Accessed August 20, 2020.

3. Vabret N, Britton GJ, Gruber C, et al. Immunology of COVID-19: current state of the science. Immunity. 2020. doi:10.1016/j.immuni.2020.05.002

4. Post N, Eddy D, Huntley C, et al. Antibody response to SARS-CoV-2 infection in humans: a systematic review. Pap Prep.

5. De Brun C, Farrow E, Gledhill R, et al. Covid-19 Daily Digest Endnote Library. 2020.

6. WHO. Clinical Management of COVID-19: Interim Guidance. Geneva; 2020.

7. Rosella L, Bowman C, Pach B, Morgan S, Fitzpatrick T, Goel V. The development and validation of a meta-tool for quality appraisal of public health evidence: Meta Quality Appraisal Tool (MetaQAT). Public Health. 2016. doi:10.1016/j.puhe.2015.10.027

8. Laing AG, Lorenc A, Barrio IDM Del, et al. A consensus Covid-19 immune signature combines immuno-protection with discrete sepsis-like traits associated with poor prognosis. medRxiv. 2020. doi:10.1101/2020.06.08.20125112

9. Mazzoni A, Salvati L, Maggi L, et al. Impaired immune cell cytotoxicity in severe COVID19 is IL-6 dependent. J Clin Invest. 2020. doi:10.1172/jci138554

10. Xu B, Fan CY, Wang AL, et al. Suppressed T cell-mediated immunity in patients with COVID-19: a clinical retrospective study in Wuhan, China. J Infect. 2020;18:18. doi:https://dx.doi.org/10.1016/j.jinf.2020.04.012

11. Zhou Y, Zhang Z, Tian J, Xiong S. Risk factors associated with disease progression in a cohort of patients infected with the 2019 novel coronavirus. Ann Palliat Med. 2020;9(2):428-436. doi:http://dx.doi.org/10.21037/apm.2020.03.26

12. Carsetti R, Zaffina S, Mortari EP, et al. Spectrum of innate and adaptive immune response to SARS CoV 2 infection across asymptomatic, mild and severe cases; a longitudinal cohort study. medRxiv. 2020. doi:10.1101/2020.06.22.20137141

13. Diao B, Wang C, Tan Y, et al. Reduction and Functional Exhaustion of T Cells in Patients With Coronavirus Disease 2019 (COVID-19). Front Immunol. 2020. doi:10.3389/fimmu.2020.00827

14. Jiang M, Guo Y, Luo Q, et al. T-Cell Subset Counts in Peripheral Blood Can Be Used as Discriminatory Biomarkers for Diagnosis and Severity Prediction of Coronavirus Disease 2019. J Infect Dis. 2020. doi:10.1093/infdis/jiaa252

15. Qin C, Zhou L, Hu Z, et al. Dysregulation of immune response in patients with COVID-19 in Wuhan, China. Clin Infect Dis an Off Publ Infect Dis Soc Am. 2020;12. doi:http://dx.doi.org/10.1093/cid/ciaa248

16. Bao J, Li C, Zhang K, Kang H, Chen W, Gu B. Comparative analysis of laboratory indexes of severe and non-severe patients infected with COVID-19. Clin Chim Acta. 2020. doi:10.1016/j.cca.2020.06.009

17. Agrati C, Sacchi A, Bordoni V, et al. Expansion of myeloid-derived suppressor cells in patients with severe coronavirus disease (COVID-19). Cell Death Differ. 2020. doi:10.1038/s41418-020-0572-6

18. Mann ER, Menon M, Knight SB, et al. Longitudinal immune profiling reveals distinct features of COVID-19 pathogenesis. medRxiv. 2020. doi:10.1101/2020.06.13.20127605

19. Bai K, Liu W, Liu C, et al. Clinical Analysis of 25 Novel Coronavirus Infections in Children. Pediatr Infect Dis J. 2020. doi:https://dx.doi.org/10.1097/INF.0000000000002740

20. Chen J, Zhang ZZ, Chen YK, et al. The clinical and immunological features of pediatric COVID-19 patients in China. Genes Dis. 2020. doi:10.1016/j.gendis.2020.03.008 
medRxiv preprint doi: https://doi.org/10.1101/2020.08.24.20180679; this version posted August 29, 2020. The copyright holder for this preprint (which was not certified by peer review) is the author/funder, who has granted medRxiv a license to display the preprint in perpetuity. It is made available under a CC-BY-NC-ND 4.0 International license .

21. Zhang $\mathrm{Y}, \mathrm{Xu}$ J, Jia $\mathrm{R}$, et al. Protective humoral immunity in SARS-CoV-2 infected pediatric patients. Cell Mol Immunol. 2020;(April):2-4. doi:10.1038/s41423-020-0438-3

22. Anft M, Paniskaki K, Blazquez-Navarro A, et al. COVID-19 progression is potentially driven by T cell immunopathogenesis. medRxiv. 2020. doi:10.1101/2020.04.28.20083089

23. Thieme C, Anft M, Paniskaki K, et al. The SARS-COV-2 T-Cell Immunity is Directed Against the Spike, Membrane, and Nucleocapsid Protein and Associated with COVID 19 Severity. SSRN Electron J. 2020. doi:10.1101/2020.05.13.20100636

24. Wang F, Hou H, Luo Y, et al. The laboratory tests and host immunity of COVID-19 patients with different severity of illness. JCI Insight. 2020;23:23.

doi:https://dx.doi.org/10.1172/jci.insight.137799

25. Jiang Y, Wei X, Guan J, et al. COVID-19 pneumonia: CD8+ T and NK cells are decreased in number but compensatory increased in cytotoxic potential. Clin Immunol. 2020. doi:10.1016/j.clim.2020.108516

26. Channappanavar R, Fett C, Zhao J, Meyerholz DK, Perlman S. Virus-Specific Memory CD8 T Cells Provide Substantial Protection from Lethal Severe Acute Respiratory Syndrome Coronavirus Infection. J Virol. 2014;88(19):11034-11044. doi:10.1128/jvi.01505-14

27. Tay MZ, Poh CM, Rénia L, MacAry PA, Ng LFP. The trinity of COVID-19: immunity, inflammation and intervention. Nat Rev Immunol. 2020;20(6):363-374. doi:10.1038/s41577-020-0311-8

28. Blanco-Melo D, Nilsson-Payant BE, Liu WC, et al. Imbalanced Host Response to SARSCoV-2 Drives Development of COVID-19. Cell. 2020. doi:10.1016/j.cell.2020.04.026

29. Merad M, Martin JC. Pathological inflammation in patients with COVID-19: a key role for monocytes and macrophages. Nat Rev Immunol. 2020. doi:10.1038/s41577-020-0331-4

30. Pattterson B, Seetthamraju H, Dhody K, et al. Disruption of the CCL5/RANTES-CCR5 Pathway Restores Immune Homeostasis and Reduces Plasma Viral Load in Critical COVID-19. medRxiv. 2020. doi:10.1101/2020.05.02.20084673

31. Zhang B, Zhou X, Zhu C, et al. Immune phenotyping based on neutrophil-to-lymphocyte ratio and IgG predicts disease severity and outcome for patients with COVID-19. medRxiv. 2020:2020.03.12.20035048. doi:10.1101/2020.03.12.20035048

32. He R, Lu Z, Zhang L, et al. The clinical course and its correlated immune status in COVID-19 pneumonia. J Clin Virol. 2020;127:104361. doi:10.1016/j.jcv.2020.104361

33. Liu Y, Liao W, Wan L, Xiang T, Zhang W. Correlation Between Relative Nasopharyngeal Virus RNA Load and Lymphocyte Count Disease Severity in Patients with COVID-19. Viral Immunol. 2020. doi:10.1089/vim.2020.0062

34. Chen $R$, Sang $L$, Jiang $M$, et al. Longitudinal hematologic and immunologic variations associated with the progression of COVID-19 patients in China. J Allergy Clin Immunol. 2020. doi:10.1016/j.jaci.2020.05.003

35. Liu J, Li S, Liu J, et al. Longitudinal characteristics of lymphocyte responses and cytokine profiles in the peripheral blood of SARS-CoV-2 infected patients. EBioMedicine. 2020. doi:10.1016/j.ebiom.2020.102763

36. Luo M, Liu J, Jiang W, Yue S, Liu H, Wei S. IL-6 combined with CD8+ T cell count early predict in-hospital mortality for patients with COVID-19. JCI Insight. 2020. doi:10.1172/jci.insight.139024

37. Zhang B, Zhou X, Zhu C, et al. Immune Phenotyping Based on the Neutrophil-toLymphocyte Ratio and IgG Level Predicts Disease Severity and Outcome for Patients With COVID-19. Front Mol Biosci. 2020. doi:10.3389/fmolb.2020.00157

38. Giménez E, Albert E, Torres I, et al. SARS-CoV-2-reactive interferon-y-producing CD8+ T cells in patients hospitalized with coronavirus disease 2019. J Med Virol. 2020. doi:10.1002/jmv.26213

39. Payen $\mathrm{D}$, Cravat $\mathrm{M}$, Maadadi $\mathrm{H}$, et al. A longitudinal study of immune cells in severe 
medRxiv preprint doi: https://doi.org/10.1101/2020.08.24.20180679; this version posted August 29, 2020. The copyright holder for this preprint (which was not certified by peer review) is the author/funder, who has granted medRxiv a license to display the preprint in perpetuity. It is made available under a CC-BY-NC-ND 4.0 International license .

COVID-19 patients. medRxiv. 2020. doi:10.1101/2020.06.16.20130914

40. Liu B, Han J, Cheng X, Al E. Persistent SARS-CoV-2 presence is companied with defects in adaptive immune system in non-severe COVID-19 patients. medRxiv. 2020. https://www.medrxiv.org/content/10.1101/2020.03.26.20044768v1.

41. Gallais F, Velay A, Wendling M-J, et al. Intrafamilial Exposure to SARS-CoV-2 Induces Cellular Immune Response without Seroconversion. medRxiv. 2020.

doi:10.1101/2020.06.21.20132449

42. Grifoni A, Weiskopf D, Ramirez SI, et al. Targets of T Cell Responses to SARS-CoV-2 Coronavirus in Humans with COVID-19 Disease and Unexposed Individuals. Cell. 2020. doi:10.1016/j.cell.2020.05.015

43. Bert N Le, Tan AT, Kunasegaran K, et al. Different pattern of pre-existing SARS-COV-2 specific T cell immunity in SARS-recovered and uninfected individuals. bioRxiv. 2020. doi:10.1101/2020.05.26.115832

44. Braun J, Loyal L, Frentsch M, et al. Presence of SARS-CoV-2 reactive T cells in COVID19 patients and healthy donors. medRxiv. 2020.

45. Shomuradova AS, Vagida MS, Sheetikov SA, et al. SARS-CoV-2 epitopes are recognized by a public and diverse repertoire of human T-cell receptors. medrxiv. 2020. doi:10.1101/2020.05.20.20107813

46. Peng Y, Mentzer AJ, Liu G, et al. Broad and strong memory CD4 + and CD8 + T cells induced by SARS-CoV-2 in UK convalescent COVID-19 patients. bioRxiv. 2020. doi:10.1101/2020.06.05.134551

47. Juno JA, Tan H-X, Lee WS, et al. Immunogenic profile of SARS-CoV-2 spike in individuals recovered from COVID-19. medRxiv. 2020. doi:10.1101/2020.05.17.20104869

48. Weiskopf D, Schmitz KS, Raadsen MP, et al. Phenotype of SARS-CoV-2-specific T-cells in COVID-19 patients with acute respiratory distress syndrome. 2020:1-29.

49. Minervina AA, Komech EA, Titov A, et al. Longitudinal high-throughput TCR repertoire profiling reveals the dynamics of T cell memory formation after mild COVID-19 infection. bioRxiv. 2020. http://arxiv.org/abs/2005.08290.

50. Neidleman J, Luo X, Frouard J, et al. SARS-CoV-2-specific T cells exhibit unique features characterized by robust helper function, lack of terminal differentiation, and high proliferative potential. bioRxiv. 2020. doi:10.1101/2020.06.08.138826

51. Chandrashekar A, Liu J, Martinot AJ, et al. SARS-CoV-2 infection protects against rechallenge in rhesus macaques. Science (80- ). 2020. doi:10.1126/science.abc4776

52. Vardhana SA, Wolchok JD. The many faces of the anti-COVID immune response. J Exp Med. 2020. doi:10.1084/JEM.20200678

53. Altmann DM, Boyton RJ. SARS-CoV-2 T cell immunity: Specificity, function, durability, and role in protection. Sci Immunol. 2020. doi:10.1126/sciimmunol.abd6160

54. Huang AT, Garcia-Carreras B, Hitchings MDT, et al. A systematic review of antibody mediated immunity to coronaviruses: antibody kinetics, correlates of protection, and association of antibody responses with severity of disease. medRxiv. 2020. doi:10.1101/2020.04.14.20065771

55. Zhang Y-J, Zeng G, Pan H-X, et al. Immunogenicity and Safety of a SARS-CoV-2 Inactivated Vaccine in Healthy Adults Aged 18-59 years: Report of the Randomized, Double-blind, and Placebo-controlled Phase 2 Clinical Trial. medRxiv. 2020.

56. Jackson LA, Anderson EJ, Rouphael NG, et al. An mRNA Vaccine against SARS-CoV-2 - Preliminary Report. N Engl J Med. 2020. doi:10.1056/nejmoa2022483

57. Folegatti PM, Ewer KJ, Aley PK, et al. Safety and immunogenicity of the ChAdOx1 nCoV19 vaccine against SARS-CoV-2: a preliminary report of a phase $1 / 2$, single-blind, randomised controlled trial. Lancet. 2020. doi:10.1016/s0140-6736(20)31604-4

58. Zhu FC, Li YH, Guan XH, et al. Safety, tolerability, and immunogenicity of a recombinant adenovirus type-5 vectored COVID-19 vaccine: a dose-escalation, open-label, non- 
medRxiv preprint doi: https://doi.org/10.1101/2020.08.24.20180679; this version posted August 29, 2020. The copyright holder for this preprint (which was not certified by peer review) is the author/funder, who has granted medRxiv a license to display the preprint in perpetuity.

It is made available under a CC-BY-NC-ND 4.0 International license .

randomised, first-in-human trial. Lancet. 2020. doi:10.1016/S0140-6736(20)31208-3

59. Liu R, Wang Y, Li J, et al. Decreased T cell populations contribute to the increased severity of COVID-19. Clin Chim Acta. 2020. doi:10.1016/j.cca.2020.05.019

60. Ouyang Y, Yin J, Wang W, et al. Down-regulated gene expression spectrum and immune responses changed during the disease progression in COVID-19 patients. Clin Infect Dis. 2020;20:20. doi:https://dx.doi.org/10.1093/cid/ciaa462

61. Qin C, Zhou L, Hu Z, et al. Dysregulation of immune response in patients with COVID-19 in Wuhan, China. Clin Infect Dis. 2020. doi:10.1093/cid/ciaa248

62. Zhou Y, Zhang Z, Tian J, Xiong S. Risk factors associated with disease progression in a cohort of patients infected with the 2019 novel coronavirus. Ann Palliat Med. 2020.

doi:10.21037/apm.2020.03.26

63. Ganji A, Farahani I, Khansarinejad B, Ghazavi A, Mosayebi G. Increased expression of CD8 marker on T-cells in COVID-19 patients. Blood Cells, Mol Dis. 2020;83 (no pag(102437). doi:http://dx.doi.org/10.1016/j.bcmd.2020.102437

64. Liu Q, Fang X, Tokuno S, et al. Prediction of the Clinical Outcome of COVID-19 Patients Using T Lymphocyte Subsets with 340 Cases from Wuhan, China: A Retrospective Cohort Study and a Web Visualization Tool. SSRN Electron J. 2020.

doi:10.2139/ssrn.3557995

65. Wang $\mathrm{F}$, Hou H, Yao Y, et al. Systemically comparing host immunity between survived and deceased COVID-19 patients. Cell Mol Immunol. 2020. doi:10.1038/s41423-0200483-y

66. Dong $\mathrm{X}$, Wang M, Liu S, et al. Immune characteristics of patients with coronavirus disease 2019 (COVID-19). Aging Dis. 2020;11(3):642-648. doi:10.14336/AD.2020.0317

67. Liu Z, Long W, Tu M, et al. Lymphocyte subset (CD4+, CD8+) counts reflect the severity of infection and predict the clinical outcomes in patients with COVID-19. J Infect. 2020;10. doi:http://dx.doi.org/10.1016/j.jinf.2020.03.054

68. Du H, Dong X, Zhang J, et al. Clinical characteristics of 182 pediatric COVID-19 patients with different severities and allergic status. Allergy. 2020. doi:10.1111/all.14452

69. Bai K, Liu W, Liu C, et al. Clinical analysis of 25 COVID-19 infections in children. Pediatr Infect Dis J. 2020. doi:10.1097/INF.0000000000002740

70. Chen J, Zhang ZZ, Chen YK, et al. The clinical and immunological features of pediatric COVID-19 patients in China. Genes Dis. 2020.

doi:http://dx.doi.org/10.1016/j.gendis.2020.03.008

71. Zhang $\mathrm{Y}, \mathrm{Xu}$ J, Jia R, et al. Protective humoral immunity in SARS-CoV-2 infected pediatric patients. Cell Mol Immunol. 2020. doi:10.1038/s41423-020-0438-3

72. Ni M, Tian FB, Xiang DD, Yu B. Characteristics of inflammatory factors and lymphocyte subsets in patients with severe COVID-19. J Med Virol. 2020. doi:10.1002/jmv.26070

73. Duan L, Zhang S, Guo M, et al. Epidemiological and clinical characteristics in patients with SARS-CoV-2 antibody negative probable COVID-19 in Wuhan. medRxiv. 2020. doi:10.1101/2020.06.18.20134619

74. Hartman AL, Nambulli S, McMillen CM, et al. SARS-CoV-2 infection of African green monkeys results in mild respiratory disease discernible by PET/CT imaging and prolonged shedding of infectious virus from both respiratory and gastrointestinal tracts. bioRxiv. 2020. doi:10.1101/2020.06.20.137687

75. Hu Q, Cui X, Liu X, et al. The production of antibodies for SARS-CoV-2 and its clinical implication. medRxiv. 2020. doi:10.1101/2020.04.20.20065953

76. Kang CK, Han GC, Kim M, et al. Aberrant hyperactivation of cytotoxic T-cell as a potential determinant of COVID-19 severity. Int J Infect Dis. 2020. doi:10.1016/j.ijid.2020.05.106

77. $\quad \mathrm{Li} \mathrm{Y}$, Deng $\mathrm{W}$, Xiong $\mathrm{H}$, et al. Immune-related factors associated with pneumonia in 127 children with coronavirus disease 2019 in Wuhan. Pediatr Pulmonol. 2020.

doi:10.1002/ppul.24907 
medRxiv preprint doi: https://doi.org/10.1101/2020.08.24.20180679; this version posted August 29, 2020. The copyright holder for this preprint (which was not certified by peer review) is the author/funder, who has granted medRxiv a license to display the preprint in perpetuity.

It is made available under a CC-BY-NC-ND 4.0 International license .

78. Marcos-Jimenez A, Sanchez-Alonso S, Alcaraz-Serna A, et al. Deregulated cellular circuits driving immunoglobulins and complement consumption associate with the severity of COVID-19. medRxiv. 2020. doi:10.1101/2020.06.15.20131706

79. Ni L, Ye F, Cheng ML, al. et. Detection of SARS-CoV-2-specific humoral and cellular immunity in COVID-19 convalescent individuals. Immun / Rep. https://www.cell.com/immunity/fulltext/S1074-7613(20)30181-3.

80. Odak I, Barros-Martins J, Bosnjak B, et al. Reappearance of Effector T Cells Predicts Successful Recovery from COVID-19. medRxiv. 2020. doi:10.1101/2020.05.11.20096263

81. Varnaitė R, García M, Glans H, et al. Expansion of SARS-CoV-2-specific Antibodysecreting Cells and Generation of Neutralizing Antibodies in Hospitalized COVID-19 Patients. bioRxiv. 2020. doi:10.1101/2020.05.28.118729

82. Wang W, Su B, Pang L, et al. High-dimensional immune profiling by mass cytometry revealed immunosuppression and dysfunction of immunity in COVID-19 patients. Cell Mol Immunol. 2020. doi:https://dx.doi.org/10.1038/s41423-020-0447-2

83. Wen $\mathrm{W}$, Su W, Tang $\mathrm{H}$, et al. Immune cell profiling of COVID-19 patients in the recovery stage by single-cell sequencing. Cell Discov. 2020;6:31. doi:10.1038/s41421-020-0168-9

84. Yang X, Dai T, Zhou X, et al. Analysis of adaptive immune cell populations and phenotypes in the patients infected by SARS-CoV-2. medRxiv. 2020. doi:10.1101/2020.03.23.20040675. 


\section{FIGURES AND TABLES}

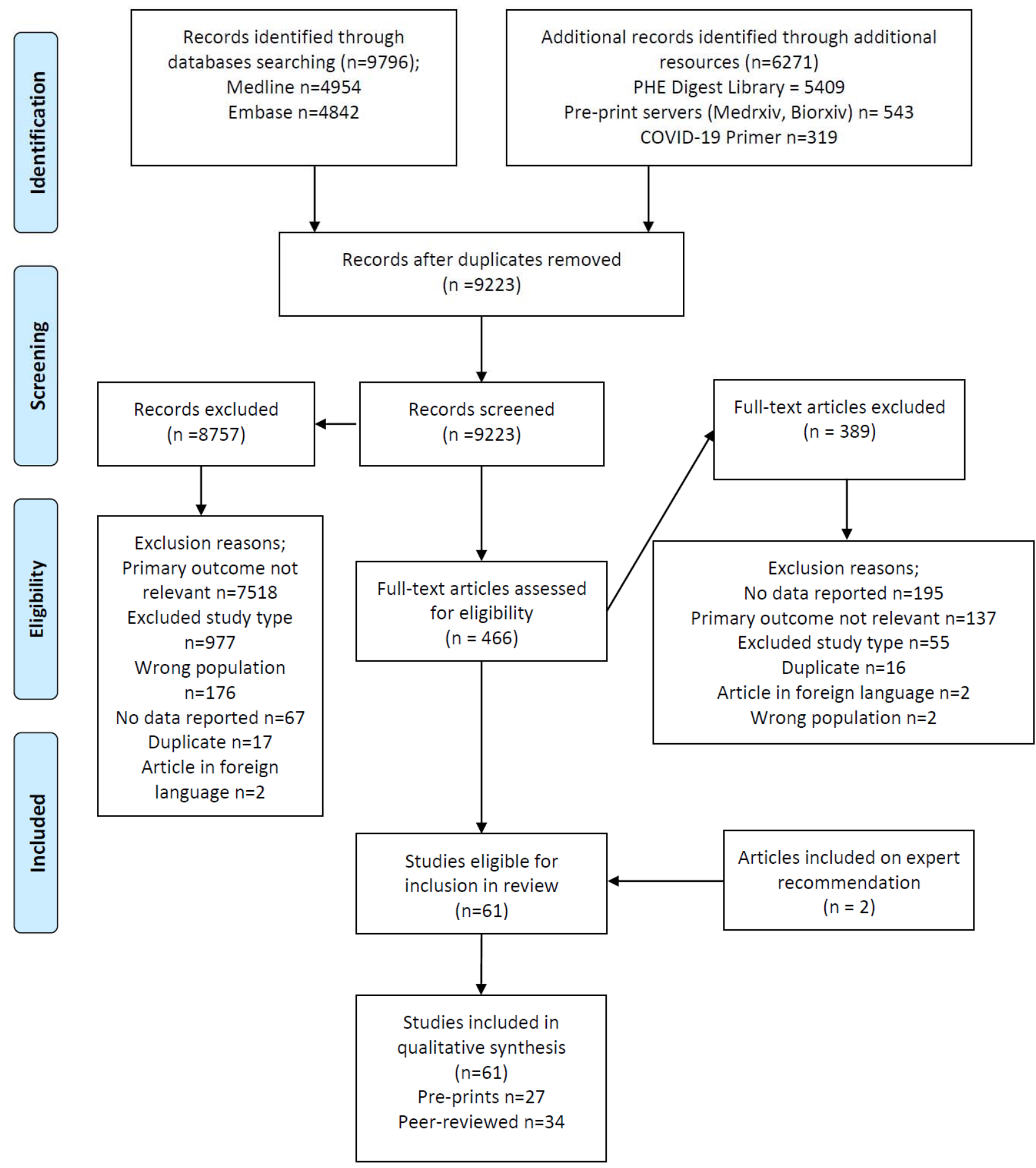

Figure 1. PRISMA flowchart documenting the search and screening process for this review. 


\begin{tabular}{|c|c|c|c|}
\hline & Characteristic & Number & $\begin{array}{c}\text { Percentage } \\
\text { of total }\end{array}$ \\
\hline & \multicolumn{3}{|l|}{ Publication type } \\
\hline & Pre-print & 27 & $44 \%$ \\
\hline & Peer-reviewed & 34 & $56 \%$ \\
\hline & \multicolumn{3}{|l|}{ Study design } \\
\hline & Case control & 26 & $43 \%$ \\
\hline & Cohort & 22 & $36 \%$ \\
\hline & Case series & 7 & $11 \%$ \\
\hline & Basic science study & 3 & $5 \%$ \\
\hline & Narrative review & 1 & $2 \%$ \\
\hline & Systematic review with meta-analysis & 1 & $2 \%$ \\
\hline & Non-randomised clinical trial & 1 & $2 \%$ \\
\hline & \multicolumn{3}{|l|}{ Study population } \\
\hline & Human & 58 & $95 \%$ \\
\hline & Animal & 2 & $3 \%$ \\
\hline & Both & 1 & $2 \%$ \\
\hline & \multicolumn{3}{|l|}{ Country from which study population was drawn } \\
\hline & China & 32 & $52 \%$ \\
\hline \multicolumn{2}{|c|}{$\begin{array}{l}\text { Europe excl. UK } \\
\text { (France, Germany, Italy, Spain, Sweden, Netherlands) }\end{array}$} & $21 \%$ & \\
\hline & USA & 3 & $5 \%$ \\
\hline & UK & 3 & $5 \%$ \\
\hline & Other countries & 6 & $11 \%$ \\
\hline & Multiple populations & 2 & $3 \%$ \\
\hline & N/A (lab or animal based) & 2 & $3 \%$ \\
\hline & \multicolumn{3}{|l|}{ Sampling context } \\
\hline & Hospital & 50 & $82 \%$ \\
\hline & Mixed hospital and community & 1 & $2 \%$ \\
\hline & Community & 6 & $10 \%$ \\
\hline & Laboratory (animal) & 2 & $3 \%$ \\
\hline & N/A (review) & 2 & $3 \%$ \\
\hline & Overall MetaQAT quality assessment & & \\
\hline & High & 10 & $16 \%$ \\
\hline & Medium & 44 & $72 \%$ \\
\hline & Low & 5 & $8 \%$ \\
\hline
\end{tabular}

Table 1. Summary of descriptive statistics for included studies. 


\begin{tabular}{|c|c|c|c|}
\hline Category & Correlate & $\begin{array}{l}\text { Dimension or } \\
\text { sub-population }\end{array}$ & Findings \\
\hline \multirow[t]{4}{*}{ Clinical } & $\begin{array}{l}\text { Disease } \\
\text { severity* }\end{array}$ & $\begin{array}{l}\text { Asymptomatic or } \\
\text { pauci- } \\
\text { symptomatic }\end{array}$ & $\begin{array}{l}\text { - One study evaluated T cell responses in asymptomatic patients }(n=20) \text { and found little change in the } \\
\text { circulating T cell frequencies within this group. }\end{array}$ \\
\hline & & $\begin{array}{l}\text { Moderate } \\
\text { disease }\end{array}$ & $\begin{array}{l}\text { - } \quad \text { Reduced numbers of both } \mathrm{CD} 4^{+} \text {and } \mathrm{CD} 8^{+} \mathrm{T} \text { cells in moderate and severe cases, alongside increased } \\
\text { numbers of activated } \mathrm{CD} 4^{+} \text {and } \mathrm{CD} 8^{+} \mathrm{T} \text { cells expressing PD-1 or Tim-3; as well as potential reductions } \\
\text { in cytotoxic potential and polyfunctionality reported in one narrative review. }\end{array}$ \\
\hline & & $\begin{array}{l}\text { Severe or critical } \\
\text { disease }\end{array}$ & 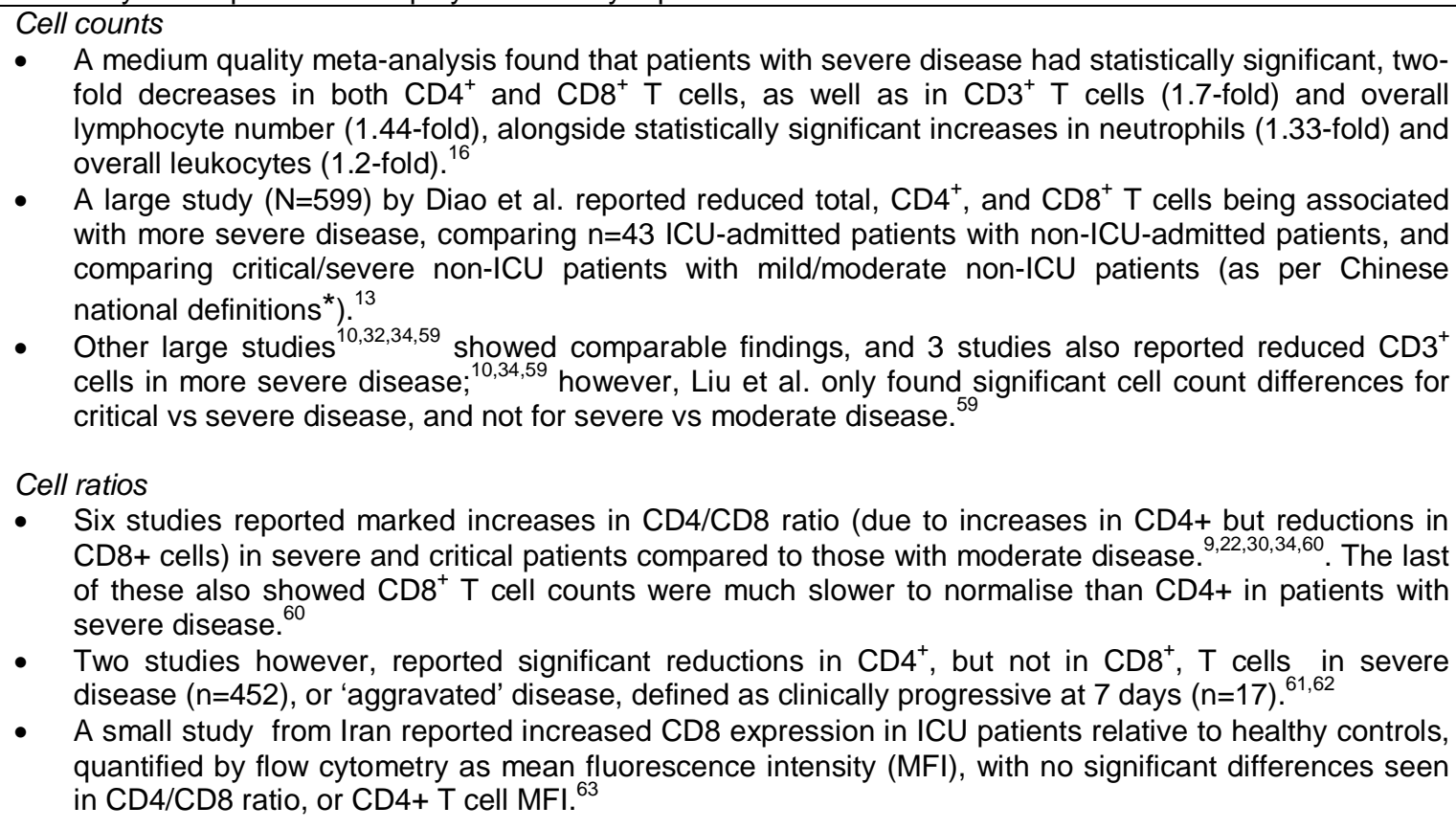 \\
\hline & $\begin{array}{l}\text { Clinical } \\
\text { endpoint }\end{array}$ & $\begin{array}{l}\text { Survival vs non- } \\
\text { survival }\end{array}$ & 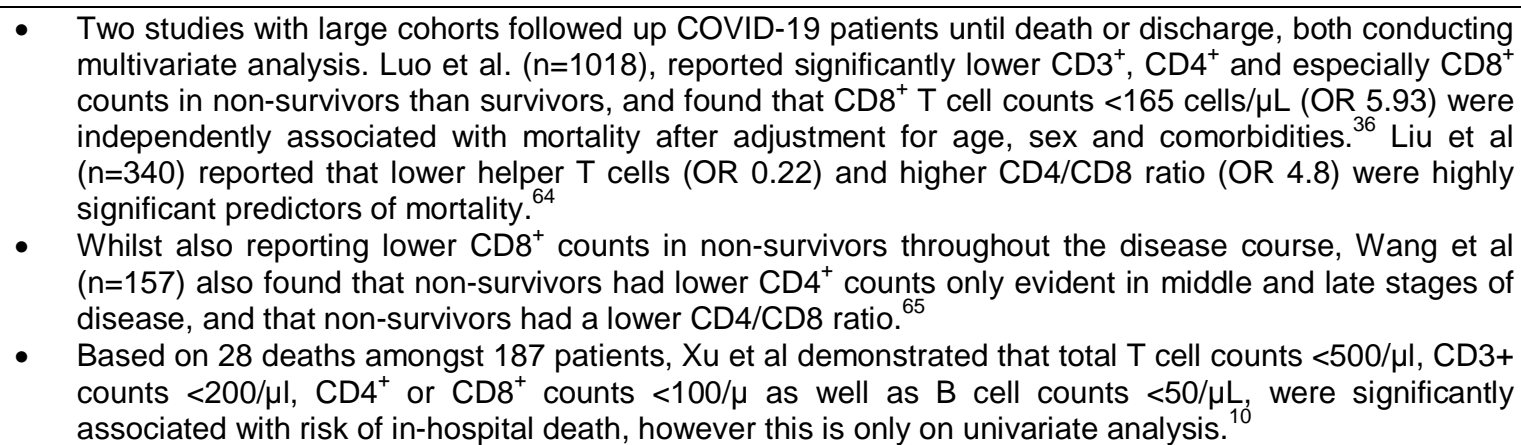 \\
\hline
\end{tabular}




\begin{tabular}{|c|c|c|c|}
\hline & & & $\begin{array}{l}\text { - In a cohort of } \mathrm{n}=548 \text {, Chen at al reported significantly elevated neutrophil-to-lymphocyte ratio (NLR), } \\
\text { platelets-to-lymphocytes ratio (PLR), reduced peripheral } \mathrm{CD}^{+}, \mathrm{CD}^{+} \text {and particularly } \mathrm{CD}^{+}{ }^{+} \text {counts in } \\
\text { non-survivors. } \mathrm{He} \text { at al. ( } \mathrm{n}=204) \text { reported that T cell levels continued to fall until death in non- } \\
\text { survivors, whilst in survivors with severe disease, levels increased after } 15 \text { days and normalised after } \\
25 \text { days of treatment. }\end{array}$ \\
\hline & & RNA persistence & 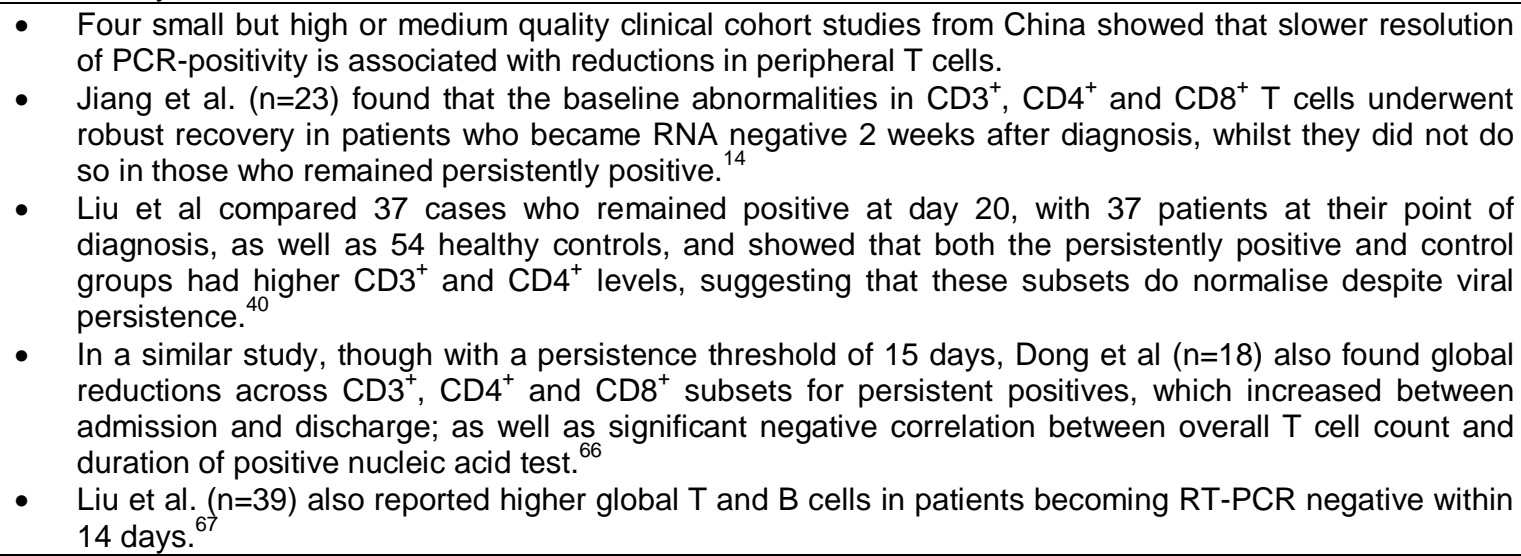 \\
\hline & Co-morbid & disease status & $\begin{array}{l}\text { - Three studies considered the effect of comorbid status, all originating from China and spanning patients } \\
\text { with non-severe, severe and critical clinical presentations. }{ }^{32,67,68} \text { Two had significant methodological } \\
\text { limitations. }{ }^{67,68} \\
\text { - One study ( } \mathrm{n}=204) \text { found significantly lower total lymphocyte and lymphocyte subset counts in patients } \\
\text { with comorbidities compared with those without (though "comorbidities" not defined). } \\
\text { - The second ( } \mathrm{n}=39 \text { ) found statistically significant differences in CD8 }{ }^{+} \text {counts between patients with } \\
\text { comorbid disease and those without ( } \mathrm{p}=0.046) \text {, but no difference in CD4 }{ }^{+} \text {counts - although here again } \\
\text { the range of comorbidities considered was not defined. }{ }^{67} \\
\text { - The final study compared outcomes in a paediatric cohort with or without "allergic disease" (not clearly } \\
\text { defined) and showed no effect on clinical course, total lymphocyte or lymphocyte subset counts. }{ }^{68}\end{array}$ \\
\hline \multirow[t]{3}{*}{ Demographic } & Age & Older adults & $\begin{array}{l}\text { - A high-quality clinical cohort study and a medium-quality case-control study, both from China, reported } \\
\text { lower T cell total and subset counts, including } \mathrm{CD}^{+}, \mathrm{CD}^{+}, \mathrm{CD} 8^{+} \text {subsets, for older patients aged } 60 \text { or } \\
\text { over. }{ }^{13,32}\end{array}$ \\
\hline & & Children & $\begin{array}{l}\text { - Four medium-quality studies - } 1 \text { case control and } 3 \text { case series - considered cellular responses in } \\
\text { children in samples from China, all showing comparable CD } 3^{+}, \mathrm{CD}^{+} \text {and CD8 }{ }^{+} \text {counts to healthy } \\
\text { paediatric controls, or where the comparison group was adults, higher } \mathrm{T} \text { cell counts across } \\
\text { subsets. }{ }^{21,69-71} \text { However, potential confounders such as disease severity or comorbidities were not } \\
\text { controlled for in these studies. }\end{array}$ \\
\hline & Sex & & $\begin{array}{l}\text { - One medium-quality case series }(\mathrm{n}=27) \text { from China examined differences in cytokine secretion by sex } \\
\text { of cases, showing reductions in } C D 4^{+} \text {and } C D 8^{+} \text {count for all patients irrespective of gender but more } \\
\text { generalised cytokine responses were observed among male participants than females, for IL-6, TNF-a } \\
\text { and procalcitonin - although the statistical significance of these differences was not tested. }\end{array}$ \\
\hline
\end{tabular}


Table 2. Evidence on clinical and demographic correlates of cellular response to SARS-CoV-2 infection from studies included in this review [ ${ }^{*}$ Disease severity was defined in various ways in included studies; for some according to intensive care unit admission; a number used the Chinese National Health Commission definition (The Notice of Launching Guideline on Diagnosis and Treatment of the Novel Coronavirus Pneumonia (NCP). 5th ed. Available online at:

http://www.nhc.gov.cn/yzygj/s7653p/202002/3b09b894ac9b4204a79db5b8912d44440/files/7260301a393845fc87fcf6dd52965ecb.pdf (accessed February 18, 2020))] 
medRxiv preprint doi: https://doi.org/10.1101/2020.08.24.20180679; this version posted August 29, 2020. The copyright holder for this preprint (which was not certified by peer review) is the author/funder, who has granted medRxiv a license to display the preprint in perpetuity.

\author{
It is made available under a CC-BY-NC-ND 4.0 International license.
}

[BLANK PAGE] 